\title{
Management of Isolated Elephant Population in Idukki Wildlife Sanctuary, Kerala, India-Problems and Prospects
}

\author{
Veeramani A*1, Balasubramanian $\mathbf{M}^{2}$ and Ramesh Babu $\mathbf{M}^{2}$ \\ ${ }^{1}$ Department of Zoology, India \\ ${ }^{2}$ Department of Biology, India
}

*Corresponding author: Veeramani Arunachalam, Assistant Professor, Department of Zoology, Government Arts College (Autonomous), Kumbakonam-612002, Tamil Nadu, India, Email: wildveera@gmail.com

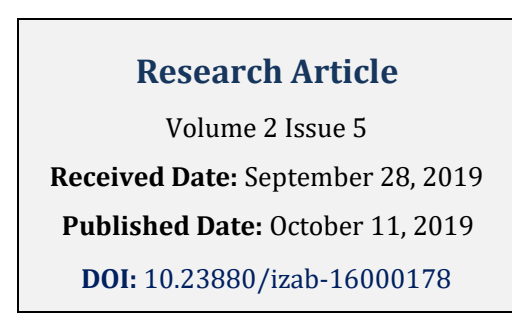

\section{Abstract}

Idukki Wildlife Sanctuary (WLS) forms part of fragmented patches of forests along the Western edge of the High Ranges. Fragmentation resulted in isolation of elephant population in Idukki WLS which is cut off from other populations. A total of 23 herds of elephants were sighted during the study period within Idukki WLS and the adjacent Ayyappankovil and Nagarampara Ranges of Kottyam Division. About twenty percent of the total herds seen were of bigger herd size (ranging from 8 to 10 individuals). There was no significant seasonal variation in the proportion of solitary elephants in the study area $\left(\mathrm{X}^{2}(1,0.01)=2.53\right)$. Observations on population structure of elephants in Idukki reveals that the adult females constituted the major age class of the population (67.92\%) followed by equal proportion of sub-adult females (7.55\%). The proportion of adult males constituted $7.55 \%$ and the sub-adult males formed $3.77 \%$. Estimation of elephants using dung count method carried out in the Idukki WLS revealed that the density of 1.072 elephants $/ \mathrm{km}^{2}$.

Observation on habitat utilization of elephants revealed that they mainly prefer the savannah grassland and moist deciduous habitats since it has more forage than the evergreen habitat. The study also explored the possibility of connecting the population of elephants in Idukki with the adjacent elephant population. Animals such as wild boar, elephant, monkeys, porcupine and sambar involve in crop damage in the human settlements within and adjacent areas of Idukki WLS. Crops such as tapioca, colacasia, yam, coconut, plantain, paddy, arecanut are found to be damaged by these animals. Cattle (goat, poultry and rabbit) lifting by wild dog from the human habitation were reported. To avoid humanwildlife conflict, timely payment of compensation, erecting/strengthening barriers such as trench, solar power fence and bio-fencing with planting of agave, Caesalpinia sappan, Plumbago sp. is suggested.

Keywords: Elephants; Density; Conflict; Idukki, Kerala 


\section{International Journal of Zoology and Animal Biology}

\section{Introduction}

The Western Ghats is considered to be one of the hotspots of biodiversity conservation due to varied habitats and high degree of endemism. However, forests in most parts of the region have been highly degraded and fragmented due to various 'developmental activities' carried out by an expanding human presence. Fragmentation of habitats results in the isolation of wildlife population that prevents the genetic flow between populations especially among the long ranging larger mammals. Idukki Wildlife Sanctuary is one of the highly fragmented forest patches in the Western Ghats and hence needs special attention for understanding and addressing the issue of biodiversity conservation in this fragmented landscape.

Knowledge of a species in relation to its conservation and associated problems are the important pre-requisites for developing any effective management strategy. Attempts had already been made to study the long-term environmental and ecological impacts due to the river valley projects in Idukki areas on biodiversity [1]. Idukki had been the focal area of several studies related to environmental impacts [2-11]. Species oriented studies in Idukki Wildlife Sanctuary are only a few and limited. Vinod, et al. [12] reported certain aspects of elephants in Idukki from one-year observation. Easa, et al. [13] studied on the status, food and feeding of larger mammals in Idukki wildlife sanctuary. However, these studies are not providing much detail on the contiguity of habitat especially of long ranging larger mammals like elephants and the measures to mitigate the problems associated.

Synchronized elephant census also carried out in the state during 1998, 2002, 2005 and 2007 shows the status of elephant population in the Wildlife Sanctuary [14-17].

The recent elephant census conducted reveals that a total number of elephants observed directly during the census period in the study area is about 76 individuals [16]. Of these, 5 adult bulls and a sub adult bull were observed. The overall and adult male to female sex ratio has been estimated as 1:10.2 and 1:11.7 respectively.

Vinod, et al. [18] found that elephants Idukki WLS spent $65 \%$ of their time feeding in dry season, while it accounted for $80 \%$ in wet season. The study revealed that elephants spent more time on feeding during wet season. However, grazing was found to be predominant in both dry season $63 \%$ and in wet season $71 \%$. The study also revealed that proportion of males in the population was very low $(2.75 \%)$ compared to females $(91 \%)$.

All studies carried out so far in the WLS revealed that the proportion of males in the population was very low and suffer due to highly skewed sex-ratio. Sixty eight plant species belonging to twenty nine families were identified as food plants of elephants, grasses being the dominant ones [13].

It is generally believed that the elephant population in Idukki WLS is an isolated one and cut off from other populations due to the discontinuity in the habitat. In order to ascertain the habitat contiguity, issues pertaining to the protection and conservation of elephants and problems associated with their habitats in Idukki landscape, a detailed and specific study was conducted. In addition to the above, the study was also focusing on the existing population structure of elephants to understand the trend over the period. The specific objectives of the study were to:

Assess the different land-use pattern in and around the Sanctuary

Monitor the population structure, composition and sexratio

$>$ Monitor the seasonality in movement pattern (between habitats and regions)

$>$ Examine the human-elephant conflict

$>$ Understand the impacts of the presence of feral cattle on elephant population

$>$ Identify and prioritize the threats involved in the management with a special focus on the habitat contiguity and Suggest measures to mitigate the problems associated to the survival of elephants in the region.

\section{Overview of the Study Area}

Idukki Wildlife Sanctuary forms part of a number of fragmented patches of forests along the Western edge of the High Ranges. The area falls between $9^{\circ} 45^{\prime}$ and $9^{\circ} 55^{\prime} \mathrm{N}$ and between $76^{\circ} 50^{\prime}$ and $77^{\circ} 05^{\prime} \mathrm{E}$ in Nagarampara Reserve Forests and forms the catchment area of ldukki Hydel Project (Figure 1). The Sanctuary with an area of $105.364 \mathrm{~km}^{2}$ including $33 \mathrm{~km}^{2}$ water spread area of the Idukki reservoir is contiguous with adjacent forested areas of Ayyappankoil and Nagarampara Forest Ranges of Kottayam Forest Division and Thodupuzha Range of Kothamangalam Division. Excluding the $33 \mathrm{~km}^{2}$ of water spread area of the reservoir; the actual area of the Sanctuary is about $72 \mathrm{~km}^{2}$. The area is of undulating 


\section{International Journal of Zoology and Animal Biology}

terrain with the elevation ranging from 800 to $1272 \mathrm{~m}$.

(1272 m).

The highest peak in the Sanctuary is Kizhukalachimala

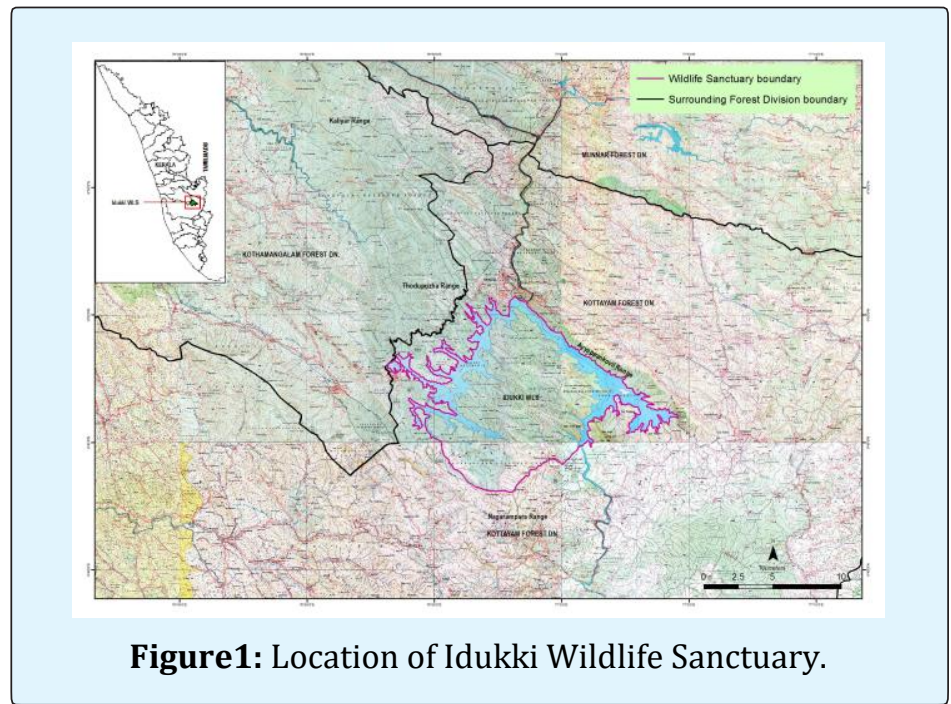

\section{Types of Vegetation}

The vegetation structure of Idukki Wildlife Sanctuary has been classified into west coast tropical evergreen forest, west coast tropical semi-evergreen forest, and moist deciduous forest and savannah grasslands [19]. Due to degradation and fragmentation the structure of original vegetation has changed hence presently it is difficult to differentiate the formations based on floristic composition. Thus the existing vegetation in Idukki WLS is classified into 4 categories (Figure 2 \& Plate 1 ).

- Wet-evergreen or Semi-evergreen

- Moist Deciduous Forest with Savanna Grassland

- Degraded stages of Moist Deciduous Forests and

- Monocultures (plantations)/Miscellaneous

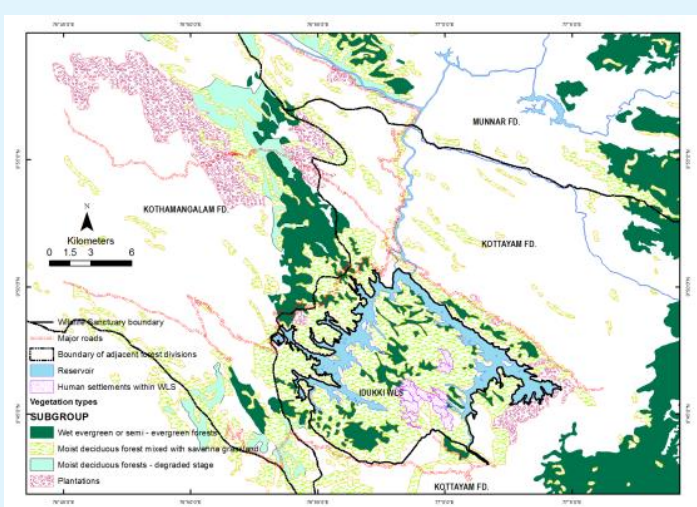

Figure 2: Vegetation in and around Idukki Wildlife Sanctuary.

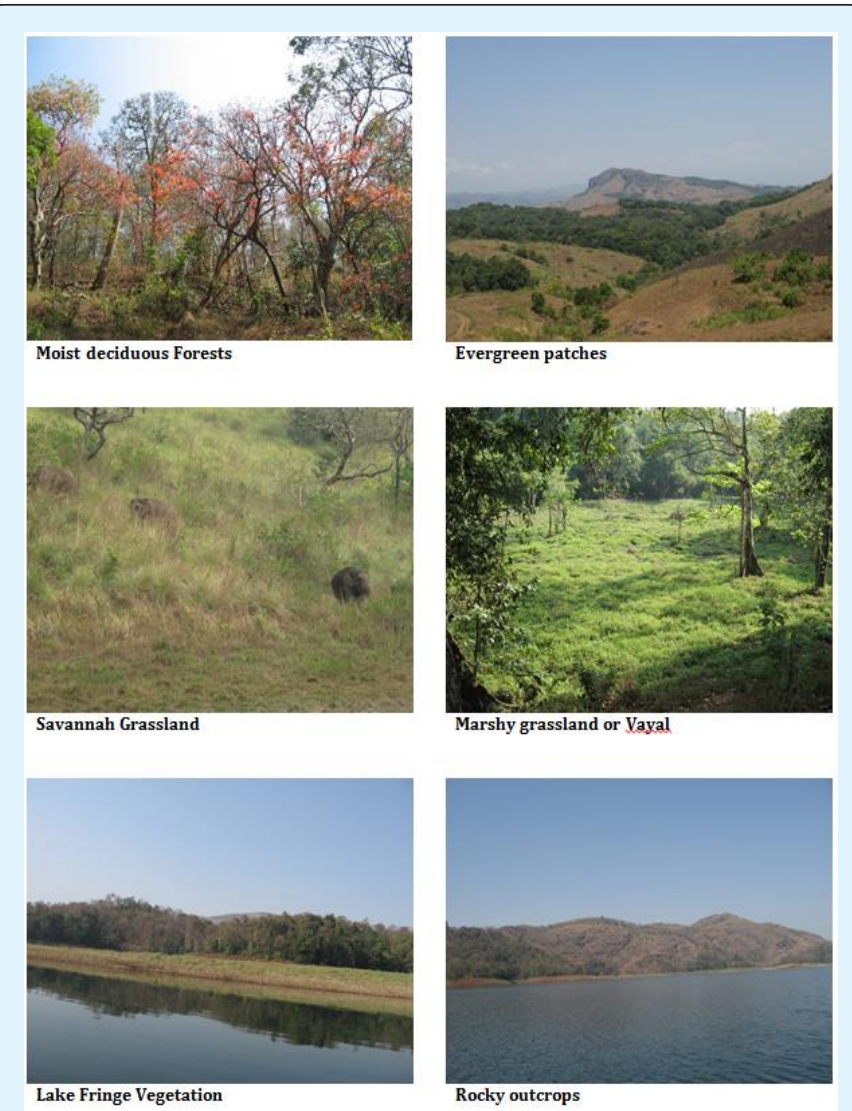

Plate 1: Different types of vegetation and habitats seen in Idukki wildlife Sanctuary. 
The evergreen forests in the WLS are highly fragmented and degraded to secondary moist deciduous forests. This type of forest is found in Vagavanam, Anjilithandu, Vallakkalmalai, Kizhukalachimala, Vattikadu and Chembagassery areas. Some of the tree species found in this type include Cullenia exarillata, Artocarpus heterophyllus, Vateria indica, Dipterocarpus indicus, Paluquium ellipticum, Canarium strictum, Calophyllum apetalum, Dysoxylum malabaricum, Elacocarpus tuberculatus, Hopea parviflora, Holigarna arnottiana, Myristica dactyloides, Aporusa lindleyana and Cinnamomum zeylanicum. Canes and ferns are also found in this habitat. The under growth consist of Strobilanthus, Calamus, Pandanus, Curcuma and Clerodendrum infortunatum.

High degradation of this forest is found at Anappallam, Muthichola, Kannamkayam, Vellakanam, Konnakuzhi, and Arakkapadam. The dominant species found in this habitat are Persea macrantha, Chionanthus mala-elangi, Macaranga peltata, Bischofia javanica, Artocarpus hirsuta, Lagerstroemia microcarpa, Cinnamomum zeylanicum etc.

Among the habitat types, moist deciduous forest interspersed with savanna grassland occupy the major area of the sanctuary especially along the periphery of the reservoir and in Vanamavu, Anappalam, Konnakkuzhi, Karimundi, Nellari, Vellakamalai, and Vellakanam. Tectona grandis, Dalbergia latifolia, Lagerstroemia microcarpa, Grewia tiliijolia, Vitex altissima. Xylia xylocarpa, Pterocarpus marsupium, Careya arborea, Dillenia pentagyna, Emblica officinalis, Haldina cordifolia, Schleichera oleosa and Randia brandisii are the major tree species found in this habitat.

Exotic weeds such as Lantana camara and Eupatorium odoratum are found abundant in this habitat. Apart from the above, Zizyphus xylopyrus and Bambusa arundinacea are also found this habitat. Amidst this habitat large extent of grassland consisting of species such as Themeda cymbaria, Cymbopogon sp. and Heteropogon contortus found along the hill slopes and on top of the hillocks. Anogeissus latifolia, Bridelia retusa, Emblica officianalis, Careya arborea, Kydia calycina that are resistant to fire are found scattered in grassland.

Vayals (marshy lands) dominated with grasses and sedges are found mainly in Vellakamaly and Vettilapara region. Small streams originate from these marshy meadows which are intensive being used by herbivores during peak dry season. These areas are always wet and moist which in turn help in keeping fresh and green vegetation throughout the year. Members of Cyperacea and Eriocaulacea are common in these areas. Vayals are mainly formed by deposition of topsoil from the neighbouring areas. This soil in long run becomes clay and non-porous. Due to this reason water does not reach deep in to the soil below. Subsequently the areas become water logged. Hydrophytes and Cyperaceae members along with grass species colonize the area. Vayals in Idukki WLS are also the habitat for Eriocaulacea members.

Fresh grasses and sedges make these habitats ideal for herbivore community. Since there is availability of fresh grasses, wild animals prefer these habitats in all seasons of the year. Exotic weeds like Lantana camara and Eupatorium odoratum invaded in this habitat especially on the fringes. Since the soil in marshy vayals is rich, these weeds rapidly get established. The vigorous growth of weed often makes the area inaccessible to herbivores and suppresses the indigenous species. In long run the area becomes less in water content and ultimately becomes thickets or woodlands.

\section{Animals}

Elephant is one of the larger mammals in the Idukki Wildlife Sanctuary. Since this is an isolated sanctuary, the elephants cannot migrate to other forested areas. They used to swim across the lake to move adjoining forest areas of Nagarampara, Ayyappancoil and Thodupuzha forest ranges but return to the sanctuary as the other area are surrounded by human habitation and mostly disturbed.

Other mammal species recorded in the sanctuary are sambar deer, barking deer, mouse deer, wild boar, porcupine, bonnet macaque, black-napped hare, common mongoose, wild dog, and Malabar giant squirrel. Presently there were no evidences of tiger or leopard in the sanctuary. Gaur which was found once in the region is extinct.

The area is rich in bird life. A total of 172 species of birds have been recorded in the sanctuary. White cheeked barbet, red whiskered bulbul, yellow browed bulbul, jungle crow, racket-tailed drongo and hill myna were seen throughout the area. Grey jungle fowl, blossom-headed parakeet, scarlet minivet, crested serpent eagle, common iora, golden-fronted chloropsis and purple sunbird were also seen uniformly distributed in the area. 


\section{International Journal of Zoology and Animal Biology}

\section{Methods}

\section{Assessment of Land-Use Pattern and Habitat Contiguity}

Different land-use pattern such as natural vegetation, plantation, human settlements, cultivation of crops, etc. was assessed by perambulation in the field, and verification of existing land use maps by ground truthing. Using the information collected from observation and ground truthing, a map of land-use pattern was generated to ascertain the habitat contiguity.

\section{Population Structure}

Structure and age/sex ratio: The population structure of family groups and solitary males was collected from systematic visits to each habitat within the study area during the study period. The entire study area was thoroughly perambulated during morning and evening hours for direct observation of elephants. While encountering an elephant or herd of elephants the age is estimated for all individuals in the herd using the height.

Various methods have been developed and employed for ageing elephants in the wild both in Africa and Asia. One of the methods is measuring the degree of tooth eruption and wear upon which growth curves have been based. The other method of ageing was investigated by Laws, et al. [20] and Laws, et al. [22] on the relationship between the shoulder-height and the age of elephants and found that it appeared to be a very good parameter for describing linear growth of elephants. Based on this principle Sukumar, et al. [22] developed a chart from the data on the shoulder height of captive elephants using the von Bertalanffy equations. This chart was used in the present study to assess the age of individuals. Information on date, time, location, size, sex-composition and family structure are collected during each encounter of elephants.

Time spent on each habitat was also been recorded to analyse the habitat utilization of elephants in the study area. Habitat-wise information on the food species of elephants in each area also collected during the visits to field.

For analyzing the information on population structure, the observed groups was placed in three different types of classifications viz.,
- Type A: All individual in the group or herd could be classified-For estimating the population structure and sex ratio, this herds or individuals classified under this type only was used. Care was taken to avoid/exclude the re-sightings of family groups and solitary males during the analysis.

- Type B: All the individuals in the group could not be classified, otherwise only a fair number of individuals classified which include the presence or absence of adult males - The herds classified under these two categories was used to calculate the proportions of adult males in the population (the total number of adult male sightings/the total number of individuals recorded in Type A and Type B sightings).

- Type C: No classification of individuals made-This type was not be used for any of the analysis said above.

\section{Population Estimation}

Block Count: The population was estimated using the direct observation in the block count method. For this purpose, the study area was divided into three or four sub-units and each unit was perambulated simultaneously. Effort was taken to identify individuals of herds during this exercise to avoid recounting. All the information provided in the data sheet was gathered during the survey.

Transect Method-Indirect Count: Information on the dung of elephants such as perpendicular distance of each dung pile from the transect line was collected from the transects in each enumeration. The data thus gathered was analyzed using the software 'Distance' for deriving the density of dung piles per unit area. To estimate the population of elephants in the study area using the density of dung piles, the decay rates in different habitats are needed. For this purpose, the dung decay rates were followed the figure used by KFRI [16].

\section{Monitoring Seasonal Movement and Habitat Utilization}

The seasonal movement of elephants in different habitats was worked out using the data from the transects and block count method. Percent effort (distance covered and time spent by the enumerator in each habitat) was compared with the number of sightings along with the total number of individuals in each habitat to derive the information on seasonal movement pattern of elephants in each habitat. 


\section{International Journal of Zoology and Animal Biology}

\section{Human-Elephant Conflict}

Elephant habitats are disappearing fast as humans increasingly develop a stake in its land. Unlike most other species, elephant do not simply disappear from these interfaces of human and elephant lands. The result on human-elephant conflict, initially detrimental to humans as their crops, property and sometimes lives are destroyed by elephants, then detrimental to the elephants as human react. For decades, farmers, plantations, and governments throughout Asia's elephant range countries have tried to mitigate conflict with elephants, using a range of options from abandoning fields they were unable to protect to culling crop-raiding elephants.

In addition, direct observation was made in the human settlements and crop field for the damage caused by elephants, if any, during the study period. While visiting the crop field for assessing the damage caused by elephants, information such as number of elephants involved in the damage, type of damage, crops damaged, frequency of visiting, etc. were collected. These data was analyzed for deriving the extent of human-elephant conflict in the study area.

\section{Threat to the Population Management}

The factors that led to habitat degradation (like grazing, fire, etc); habitat and species loss in the study area was identified for developing future management strategies. All the existing and potential threats especially to the elephant population including contiguity of habitat were also thoroughly analyzed through direct observation and discussions with the park authorities and prioritized the same for eliciting management strategies.

\section{Results}

\section{Assessment of Land-Use Pattern and Habitat Contiguity}

Idukki landscape is importantly known for the splendid green mountains and streams. The district was named after the mighty Idukki Hill and has definite physical characteristics. A major portion of the district is covered by dense and degraded forests, and extensive tea, coffee and cardamom plantations. Nearly $96 \%$ of the total area of the district comes under the high land area covered by rugged mountains and deep valleys.

History of deforestation: The early history of the Idukki region is obscure. However, the modern history starts with the advent of European planters to this region. In
1877, the Raja of Poonjar sold 227 Miles $^{2}$ of Kannan Devan hills, a totally unexplored tract covered with thick forest to a British Planter for establishing estates. Planters were the first migrants to the high range region covered by dense forest. While establishing estates, numerous roads were opened, transports were organized, dwelling places and factories were built and productions rose rapidly in the succeeding years. The first hydroelectric scheme of the State, the Pallivasal Hydroelectric Project, was initially constructed by the tea companies for the industrial use and was commissioned in 1939. Deforestation process started in the high ranges with advent of the plantation industry by the end of the $19^{\text {th }}$ century.

Vast areas of evergreen forest in the Idukki region were totally destroyed in connection with the construction of numerous hydro-electrical projects, roads, factories and associated infrastructures. Idukki hydroelectric project is one among the sequences. About $27 \mathrm{~km}^{2}$ of virgin evergreen forests in the Idukki valley was clear felled for the development of Idukki hydro-electric project in 1976. The tribes who lived in the Idukki gorge (the present water spread area) were resettled on the upper reaches of the valley.

Subsequently, with the intention of conserving the remaining land which forms the catchment of the reservoir and is highly necessary for the existence of this project, the main land along with the water body was notified as a sanctuary in the same year 1976. An extent of $105.364 \mathrm{~km}^{2}$ forest area in Nagarampara Reserved Forest which is the catchment area of ldukki Hydel Project was declared (vide GO No. 7898/FM3/76/AD dated 9.2.1976) as Idukki Wildlife Sanctuary. The declared area includes an extent of $33 \mathrm{~km}^{2}$ of submerged area of the Idukki reservoir which consist of 3 dams namely Idukki, Cheruthony and Kulamavu. The WLS region includes the resettled tribal communities from the Idukki gorge.

Forests in Idukki landscape: The WLS is the leftover part of the forests in high ranges that represents high fragmentation. Within WLS, there are 12 hill men settlements and the people therein depend on the WLS for their subsistence and collect fire wood and NWFP, and grazing cattle.

Three sides of the WLS excepting the southern part of the sanctuary are surrounded by the Idukki reservoir. The vegetation in the WLS is contiguous with adjacent forested areas of Ayyappankoil and Nagarampara Forest 


\section{International Journal of Zoology and Animal Biology}

Ranges of Kottayam Forest Division and Thodpuzha and Kaliyar Ranges of Kothamangalam Forest Division. There is lack of clarity on the south-east boundaries of WLS over a teak plantation which is presently being maintained over 30 years by the authorities of Nagarampara Range of Kottayam Forest Division.

The vegetation in the south-east corner of the WLS is extended to a patch of teak plantations in Nagarampara Range of Kottayam Forest Division which is very rarely being visited by elephants. Otherwise, the entire southern part of the WLS is totally occupied by human habitations viz., Mattuthavalam, Muthambadi, Vadavukkad, Kuvalayattam, Uluppuni, Kattamala and large extent of Kattamala tea estate which is on the catchment of Cheruthoni Ar. In addition, numerous road networks to the human habitations also exist on the southern side of the WLS which include a major road between Ayyappankovil and Muttam. Though few highly degraded patches of forests with smaller extent occur amidst the human habitations, they are highly degraded and are not suitable for larger animals to live in.

On the east, the Sanctuary is bounded by a hill ridge of Kuravan Mala and Kalyana thandu. Along this ridge, a narrow patch of forest occurs in Ayyapankovil Range of Kottayam Forest Division on the eastern side of the WLS boundary. This patch is also highly degraded with intense human pressure and mostly occupied by rocky areas. A major heavy-traffic road between Kattappana and Painavu is running parallel to the forest patch. Human habitations such as Valavara, Ettammile, Pathammile, Naragakandam and Idukki exist on the road side. There is no forest further on the eastern side where cardamom cultivations exist in larger extent and potential habitats exist miles away.

Towards north of the WLS, small townships such as Cheruthoni and Painavu exist. Between Painavu and Keerithodu townships, smaller isolated patches of forests of Nagarampara RF are found that has no connectivity with the Thodupuzha RF on their western side. Here also, the situation is the same like on the eastern side of the Sanctuary; hence no possibility of connectivity occurs in this region.

The western side of WLS has habitat contiguity in the Kottayam and Kothamangalam Forest Divisions that provide access to animals live within WLS to temporarily move out for a shorter distance only towards north-west direction. Kulamavu colony exists in Kottayam Forest Division on the south-west portion of the WLS which prevent the contiguity to the Arakkulam RF where remnant of isolated forest patches in smaller extent and large extent of Eucalypts plantations occur. The Arakkulam RF is flooded with human habitations and already converted to tapioca and tea, coffee, rubber plantations. Smaller extent of forest on the western side of the reservoir and Kulamavu colony is being used by wild animals that swim across the reservoir. Forest patches on the northern side of Valiyakunnu are also being used by wild animals including elephants.

Towards north-west, the forest of the WLS is connected to a linear patch of forest in Thodupuzha RF. This patch of forest extends from the WLS in the south and extends upto Tommankuthu on the north. The extent of this patch of forest is about $105 \mathrm{~km}^{2}$, of which a large extent is under monoculture (43\%), followed by highly degraded moist deciduous forest with grassland (18\%) and degraded stages of evergreen to semi evergreen forest $(10 \%)$. Remaining area consist of smaller extent of degraded patches of forests and rocky outcrops which are not potential habitat for wild animals. Though the forest is a linear in nature, the animals are found use this habitat and elephant occasionally move from the WLS towards north-west up to Tommankuthu. Beyond Tommankuthu the forest is totally cut off on the northern part and no potential connectivity can be established as the contiguous habitat is miles away from this location. The existing forest link in Thodupuzha RF is also facing severe anthropogenic pressure as numerous human habitations exist in the surrounds. Two major roads with heavy vehicular traffic (between Painavu and Kulamavu colony and between Maniyarankudi and Pariyaram) pass through this forest patch that hinder the movement of elephant. The elephants were found to move from the WLS to the Thodupuzha RF through Chellamudi, Mundupadi thandu, Meenmutti and then the western side of Kottapara. From here they move through western side of Kottapara and through Nedumpara mudi (which is of primarily rocky region) and then towards north-west via Kaithapara (where a heavy vehicular traffic road between Maniyarankudi and Pariyaram passes through), Toppi mudi, Kuzhimattam and reaches near Thommankuthu.

This elephant habitat is drained by two water sheds viz., Periyar River and Kaliyar Puzha. Within WLS, two main rivers flowing through the sanctuary are Periyar and Cheruthoniyar and also a number of tributaries of these rivers. Periyar which is $227 \mathrm{~km}$ long is the second largest river of Kerala which originates from Sivagiri in the south east part of the district touches all the taluks of the district. As per official records more than $50 \%$ of the area 


\section{International Journal of Zoology and Animal Biology}

is under forest, but the actual area under forest is very less due to illegal deforestation and human habitations. Agricultural sector is pre-dominant by perennial crops like cardamom, tea, rubber, coconut, pepper etc. Area under paddy is very limited in this region.

The people belonging to the settlements are involved in various Eco development activities in such a way that the ecosystem is least disturbed. The sanctuary offers opportunity for regeneration of degraded land and scientific management of this fragile ecosystem.

The habitat of WLS is contiguous towards north-west to Thodupuzha RF and cut off at Tommankuthu. Hence this landscape is totally isolated and cut off from the main tract of elephant habitats extending from Munnar Forest Division on the north and Periyar Tiger Reserve on the south. In the entire landscape, the forest surrounded by the reservoir is the only congenial habitat for wildlife without much pressure as found in other regions of the landscape.

\section{Population Structure}

The present frequency distribution of different age and sex classes of elephants, based on 23 direct sighting of elephants recorded during the study period in and around the WLS is given in Figure $3 \&$ Plate 2 . The adult females constituted $67.92 \%$ of the population and the adult males are only $7.55 \%$. The sub adult females are $7.55 \%$ whereas the sub adult male has only $3.77 \%$ of the total population. Juveniles (5.66\%) and calves (7.55\%) were of low proportion.

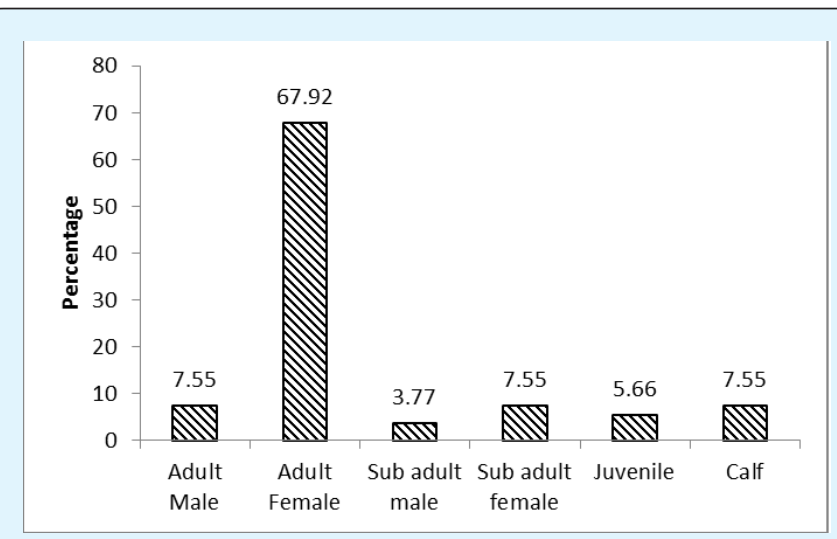

Figure 3: Population structure of elephants sighted during the study period.

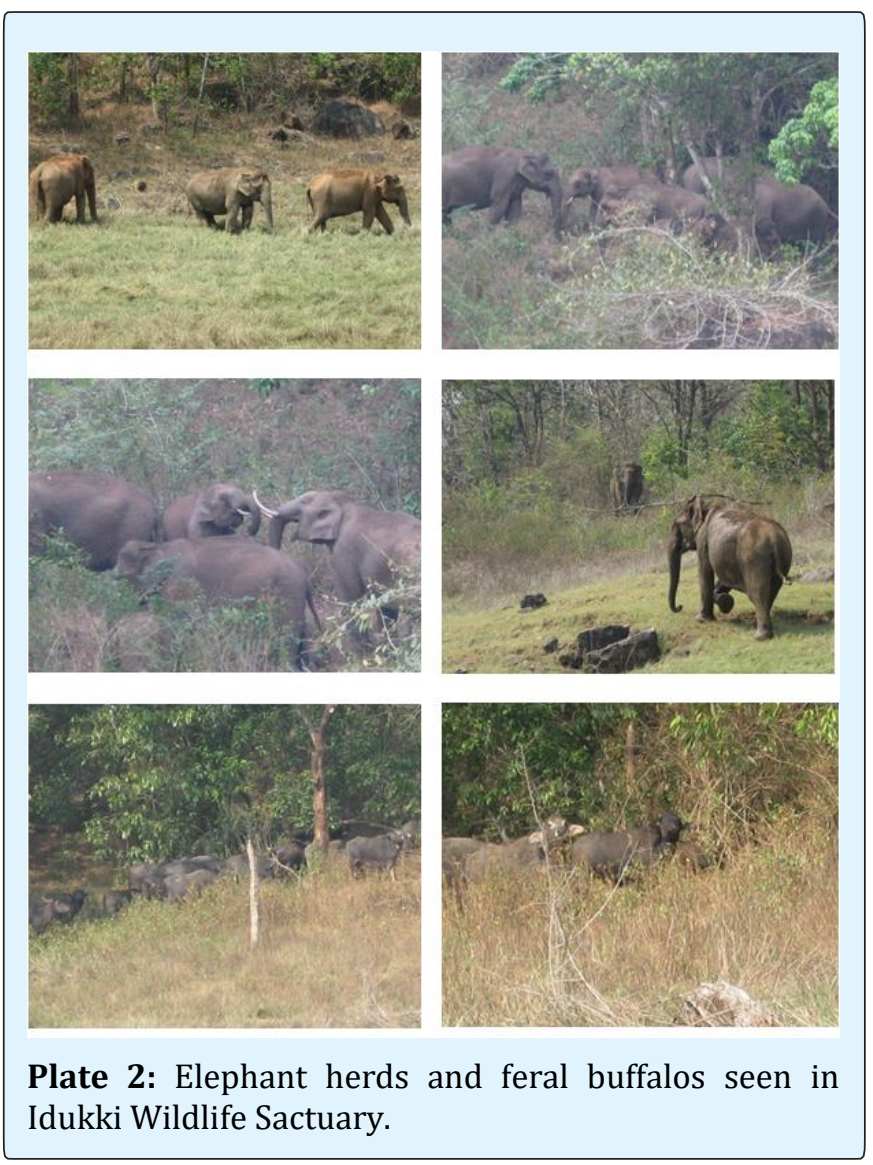

Population structure of elephants: Of the 23 herds of elephants sighted during the study period, herd sizes of 1 to 5 individuals were the commonest (60\%) of the total sightings. The rest were in bigger herds ranging from 8 to 10 individuals.

There was no significant seasonal variation in the proportion of solitary elephants in the study area $\left(\mathrm{X}^{2}(1\right.$, $0.01)=2.53$ ). Of the total 23 direct sightings of elephants, four herds were sighted in Nagarampara Range and three in Ayyappankovil Range. Maximum number of elephants was sighted near Sembagassery Forest Station $\left(9^{\circ} 49^{\prime}\right.$ 24.5" $\mathrm{N}$ and $76^{\circ} 59^{\prime} 26.1^{\prime \prime} \mathrm{E}$ ) with 10 elephants including 2 calves. Of which, no males were seen. Another herd of 8 individuals including a calf were sighted near Nelladithodu ( $9^{\circ} 46^{\prime} 64.8^{\prime \prime} \mathrm{N}$ and $76^{\circ} 56^{\prime} 41.3^{\prime \prime}$ E) area of which, 2 adult females were aging above 40 years, 2 individuals were between 35-40 years and one was about 30 years old. Two male elephants were also seen in the same herd of which one was about 25 years old and another one was 8-10 years old. 
A comparison of sighting of elephants recorded in Idukki Wildlife Sanctuary is given in the Table 1. Except 2009, all figures given in the Table are for the Idukki Wildlife Division that consists of Idukki and Thattekad Wildlife Sanctuaries. The figure of 2009 includes elephant sightings in Idukki Wildlife Sanctuary and adjacent Forest Ranges of Ayyappankovil, Nagarampara and Thodupuzha.
Solitary sightings of females: Of the total sightings, 5 sightings were of solitary females that were sighted far away from the elephant herds. Among the solitary females sighted, 2 were of 35 to 40 years old and 2 were 15 to 20 years old. The remaining two individuals were of subadult stage (from 12 to 15 years old). All females sighted solitarily were of good health except an individual that was estimated to be around 40 years.

\begin{tabular}{|c|c|c|c|c|c|c|c|c|c|c|}
\hline Year & Adult Male & Makhna & Adult Female & & Sub Adult Female & Juvenile & Calf & Un Sexed & Total & Density \\
\hline 1997 & 0 & 0 & 22 & 0 & 1 & 1 & 0 & 0 & 24 & 0.4858 \\
\hline 2002 & \multicolumn{7}{|c|}{ Data not available } \\
\hline 2005 & 5 & 0 & 51 & 1 & 4 & 5 & 2 & 8 & 76 & 1.7159 \\
\hline 2007 & 6 & 1 & 45 & 1 & 2 & 4 & 6 & 0 & 65 & 1.0693 \\
\hline $2009 *$ & 4 & 0 & 36 & 2 & 4 & 3 & 4 & 0 & 53 & 1.2045 \\
\hline
\end{tabular}

*Present study

Table 1: Comparison of elephant sightings in Idukki Wildlife Sanctuary.

Though, closely related female elephants always live in herds since birth, the observation of solitary female elephants in and around Idukki WLS are found to be strange and abnormal. In normal population, aged female or individuals with ailment or with walking/moving disability would be left alone as other members of the herd cannot expense their regular movement for one member in the herd.

Lesser herd size with 2 to 4 or 5 individuals could be due to scarcity of food as is observed in other normal population too. Solitary nature of healthy adult and subadult female individuals could be due to the scarcity of males in the population. The female who is in oestrus (16 weeks long) and especially during the ovulatory receptive period ( 2 days to a week) might be solitarily roaming around in search of bull to mate with. This is possible in a population with highly skewed sex-ratio and scarcity of males.

Density of elephants: Elephant is the prominent vertebrate found in the WLS. Density of elephants using dung count method along the line transects shows a density of 1.072 elephants $/ \mathrm{km}^{2}$ occurs in Idukki Wildlife Sanctuary. The comparison of elephant densities during various period are given in Table 2. Except 2009, all figures given in the table are for the Idukki Wildlife Division and 2009 figures are for Idukki Wildlife Sanctuary and adjacent ranges of territorial forest division. The co-efficient variants (CV) of dung density were less (12.42) in the present study compared to the results of wildlife population estimations carried out during the past.

\begin{tabular}{|c|c|c|c|c|c|c|c|}
\hline Year & Dung density & LCL & UCL & CV & Elephant density & LCL & UCL \\
\hline 1997 & 1250.1 & 895.4 & 1745.4 & 16.92 & \multirow{2}{*}{\multicolumn{3}{|c|}{ Division-wise result is not available }} \\
\hline 2002 & 1849.3 & 1157.6 & 2954.5 & 22.7 & & & \\
\hline 2005 & 2814.4 & 1315.68 & 6020.5 & 33.46 & 1.7579 & 0.8217 & 3.76 \\
\hline 2007 & 2262.3 & 1553.9 & 3293.7 & 16.97 & 1.413 & 0.971 & 2.06 \\
\hline $2009^{*}$ & 1942.4 & 1432.8 & 2973.6 & 12.42 & 1.072 & 0.924 & 2.09 \\
\hline
\end{tabular}

* Present study

Table 2: Density of elephants using dung count method in Idukki Wildlife Sanctuary. 


\section{Habitat Utilization}

The observation on the habitat utilization of elephants in and around Idukki WLS reveals that they mainly prefer the moist deciduous habitats interspersed with savanna grassland that has more forage than the evergreen to semi-evergreen habitats. The study also reveals that the elephants use the grasslands intensively for foraging. Of the total direct sightings, $40 \%$ elephant sightings were in moist deciduous forests, $51 \%$ in grassland and very few sighting in evergreen and semi-evergreen areas (Figure $4)$. But the presence of dung in evergreen areas inferred to be part of less preferred habitat. The elephants use the evergreen habitat mainly at Vagavanam areas only for migration. Since Idukki Wildlife Sanctuary don't have the connectivity towards south, elephants used to visit the evergreen patch at Vagavanam very rarely.

Though we could see few elephants in the evergreen forest, the presence of dung in these forests suggests that such forests also form part of their habitat. The nature of terrain does not appear a barrier to the movement of the elephant except perhaps the very steep cliffs. The lake too is often negotiated with elephants. They were seen in all kinds of terrain, from the lake margin through the numerous valleys and hills and, even grass-land hill tops. Elephants in Idukki used grasslands and moist deciduous forests during monsoon and savannahs grasslands and vayals during post monsoon period. Evergreen and semievergreen habitats were used more in winter and dry seasons. They found to forage on grasses like Cymbapogon flexuosus, Cyrtococcum oxyphyllum and Panicum repens almost throughout the year.

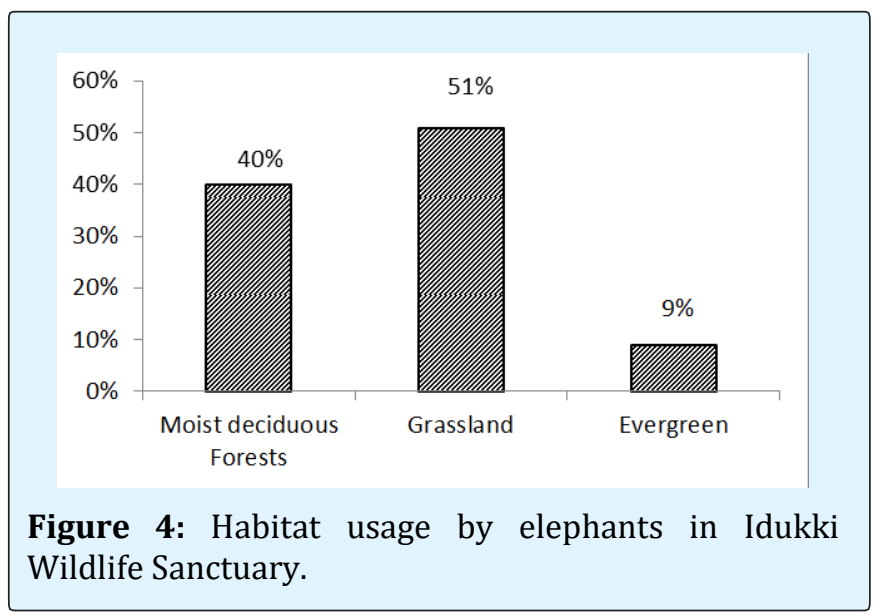

In addition to grasses they consumed leaves, barks and fruits of a number of trees. One hundred and twenty food plants of elephants in Idukki during different months of the year were identified as food of elephants. Mainly the foraging was observed directly and indirect signs such as remains of feeding sites and examining dungs. Debarking of trees is also noted as food plants of elephants. The list of food plants of elephants in Idukki Wildlife Sanctuary are given in Table 3.

\begin{tabular}{|c|c|}
\hline Arundinella ciliata & Cyperus difformis \\
\hline Arundinella mesophylla & Cyperus hackelii \\
\hline Arundinella purpurea & Cyrtococcum decarens \\
\hline Bambusa arundinaceae & Cyrtococcum oxyphyllum \\
\hline Bambusa bambos & Cyrtococcum patens \\
\hline Bothriochloa sp. & Dactyloctenium aegyptium \\
\hline Bridelia scandens & Desmodium triflorum \\
\hline Briza minor & Desmodium heterophyllum \\
\hline Cappillipedium sp. & Desmodium sp. \\
\hline Cenchrus inhiri & Digitaria ciliaris \\
\hline Centotheca lappacea & Digitaria griffithii \\
\hline Chionanthus mala-elengi & Dioscorea oppositifolia \\
\hline Chloris dolichostachya & Dioscorea pentaphylla \\
\hline Chrysopogon sp. & Drymaria cordata \\
\hline Chrysopogon zeylanicus & Elaeocarpus tuberculatus \\
\hline Clerodendron infortunatum & Elephantopus scaber \\
\hline Clerodendron thomsonae & Emilia sonchifolia \\
\hline Clittoria ternatea & Eragrostis elegantula \\
\hline Commelina erecta & Eriocaulon quinquangalare \\
\hline
\end{tabular}

Veeramani A, et al. Management of Isolated Elephant Population in Idukki Wildlife Sanctuary, Kerala, India-Problems and Prospects. Int J Zoo Animal Biol 2019, 2(5): 000178. 


\section{International Journal of Zoology and Animal Biology}

\begin{tabular}{|c|c|}
\hline Crotalaria indica & Eriocaulon parviflorum \\
\hline Crotalaria walkeri & Erythrina stricta \\
\hline Curcuma montana & Eugenia jambos \\
\hline Cyanotis arachnoidea & Grewia tiliifolia \\
\hline Cyathula prostrata & Hedychium coronarium \\
\hline Cутbopogon flexuosus & Hedyotis herbacea \\
\hline Cynodon dactylon & Helianthus sp. \\
\hline Cyperus digitatus & Helicteres isora \\
\hline Cyperus exaltatus & Hydrocotyle asiatica \\
\hline Cyperus haspan & Hydrocotyle sibthortioides \\
\hline Cyperus iria & Isachne bourneorum \\
\hline Cyperus procerus & Ischaemum rangacharianum \\
\hline Cyperus rotundus & Ixora bracheata \\
\hline Cyperus bulbosa & Ixora coccinea \\
\hline Justicia procumbels & Polygonum chinense \\
\hline Knoxia wightiana & Polygonum nepalanse \\
\hline Kyllinga bulbosa & Prosopis cinergria \\
\hline Kyllinga melanosperma & Prosopis specigera \\
\hline Kyllinga odorata & Pterocarpus marsupium \\
\hline Kyllinga nemoralis & Saccharum officinarum \\
\hline Leersia hexandra & Saccharum sp. \\
\hline Lindernia anagallis & Sauropus androgynus \\
\hline Lindernia parviflora & Schuminianthus virgatus \\
\hline Maesa indica & Scoparia dulcis \\
\hline Mimosa pudica & Sida acuta \\
\hline Mitracarpus villosus & Sida rhomboidea \\
\hline Murdannia dimorpha & Smithia conferta \\
\hline Murdannia nudiflora & Sorghum sp. \\
\hline Ochlandra travancorica & Sporobolus diander \\
\hline Osbeckia brachystemon & Striga angustifolia \\
\hline Oxalas corniculata & Strobilanthes sp. \\
\hline Panicum distichum & Synedrella nodijlora \\
\hline Panicum repens & Syzygium sp. \\
\hline Panicum trypheron & Tectona grandis \\
\hline Paspalidium flavidum & Themeda cymbaria \\
\hline Paspalum conjugatum & Themeda tremula \\
\hline Paspalum scrobiculatum & Torenia travencorica \\
\hline Pennisetum polystachyon & Tridax procumbens \\
\hline Phaulopsis imbricata & Urena sinnuata \\
\hline Phyllanthes amarus & Zizyphus jujube \\
\hline Phyllanthus emblica & Zizyphus rugosa \\
\hline
\end{tabular}

Table 3: List of food plants of elephants recorded in Idukki Wildlife Sanctuary.

\section{Settlements within WLS and Dependency on Forest}

There are twelve tribal settlements situated within the sanctuary with a total human population of about 2200 individuals. These settlements (detailed below) were formed for resettling tribals who lived in the submerged part of the Idukki reservoir. All these colonies are located amidst the sanctuary within the limit of Kizhukanam section.
a. Memmari
b. Beemanchuvadu
c. Mulla 


\section{International Journal of Zoology and Animal Biology}

d. Vakkathi

e. Kannampady

f. Mullallu

g. Punnapara

h. Kizhukanam

i. Thekkuthottam

j. Kollathikavu

k. Kathitheppan

l. Venmavu

These settlements are approachable through road via Upputhara and Kizhukanam. Even though, most of these settlements belong to the tribal communities, non-tribals are also seen staying in these settlements. The tribals belonging to these settlements are Oorali, Ulladan and Arayans. The main occupations of them are agricultural laborers and small farmers. They also depend on the forest for firewood, fodder grass, green manure, grazing their cattle, and fishing, collection small poles for construction of sheds, honey and other NWFP items.

Many of the fringe area settlers who have come during the construction of Idukki dam and associated structures are also using the sanctuary resources for subsistence. The neighbouring villages on the fringes of the sanctuary are Kothapara, Kuvalettam, Kumarikulam, Mathaippara, Narakanam, Kozhimala, Upputhara and Valakodu within the limit of Kottayam Forest Division. Most of them are also depend on agriculture as their major source of income.

Human-Wildlife conflict: Human wildlife conflict is one of the major challenges for the wildlife managers. Crop raiding is the worst manifestation of such conflicts. However, this issue in the WLS is not found to be such a vital issue as evidenced from the observation. Idukki Wildlife Sanctuary being surrounded by crop cultivation in the human habitations, often faces problem due to increasing population of marauding wild animals. Effective maintenance of protection measures such as electric fencing and elephant proof trench in the surrounds of the farmland within WLS mostly keep the wild animals away from crop field. However, timely compensation is being provided to farmers that ensures a pleasant PA-people interface.

The sanctuary management has introduced the Ecodevelopment activities during 2000's and the fringe area people are also involved in protection. Construction of Kayyalas, installation of power fencing was the major activities implemented as part of ecodevelopment. Construction of Kayyalas in some of the highly problem- prone areas helped considerably reduced crop damage by wild animals. Protection measures such as solar fencing, elephant proof trench, and bio fencing are created in almost all the human settlements bounded by Idukki WLS.

Intensity of crop damage and animals involved in crop depredation: Wild boar, elephant, bonnet monkeys, porcupine, sambar deer are the major animals causing damage to the agricultural crops. Wild boar is found to be causing more damage to the tuber crops as well as cash crops. This was followed by elephants and bonnet monkeys. Porcupine and sambar deer were also found to be causing considerable damage. Wild dog was reported occasionally to predate on the live stocks such as goat, poultry and rabbit during the study period. It was observed that the settlers mostly cultivate tuber crops such as tapioca, colacasia, alocasia (elephant yam), and other crops such as coconut, plantain, paddy, arecanut, etc. Evidences of crop damage were recorded in 85 plots, out of 160 plots surveyed. This forms about $53.1 \%$ of the total plots. However, only $23 \%$ of the total plants in these plots were damaged.

Intensity of crop damage in different settlements: The results of the survey in the settlements are summarised in Table 4. Crop raiding incidences in the plots surveyed were higher in Punnapura (35\%) followed by Memmari (30\%), Venmavu (28\%) and Kollathikavu (25\%). Rest of the settlements the percentage of raiding were comparatively less. The percentage of plants damaged was also high in Punnapura and Memmari settlements $(52.20 \%)$ followed by Venmavu $(45.77 \%)$ and Kollathikavu (38.70\%).

\begin{tabular}{|c|c|c|c|}
\hline $\begin{array}{c}\text { Sl. } \\
\text { No. }\end{array}$ & Settlements & $\begin{array}{c}\text { \% of plots } \\
\text { raided }\end{array}$ & $\begin{array}{c}\text { \% of plants } \\
\text { damaged }\end{array}$ \\
\hline 1 & Punnapara & 35 & 52.2 \\
\hline 2 & Memmari & 30 & 52.2 \\
\hline 3 & Venmavu & 28 & 45.77 \\
\hline 4 & Kollathikavu & 25 & 38.7 \\
\hline 5 & Kannampady & 22 & 32 \\
\hline 6 & Beemanchuvadu & 22 & 31.39 \\
\hline 7 & Kathitheppan & 21 & 28 \\
\hline 8 & Vakkathi & 18 & 26.31 \\
\hline 9 & Mulla & 17 & 25.24 \\
\hline 10 & Mullallu & 15 & 21.69 \\
\hline 11 & Kizhukanam & 13 & 20 \\
\hline 12 & Thekkuthottam & 10 & 13.64 \\
\hline
\end{tabular}

Table 4: Percentage plots and plants raided by wild animals in different settlements. 
Of the 85 plots raided by different wild animals, the wild boar, elephant and bonnet macaque inflicted heavy damage to the extent of $42.31 \%, 30.77 \%, 19.23 \%$ respectively. Sambar deer and porcupine caused less damage (Table 5). There were also plots damaged due to the combination of different animals.

\begin{tabular}{|c|c|c|}
\hline S. No. & Animals & Percentage of damage \\
\hline 1 & Wild boar & 42.31 \\
\hline 2 & Elephant & 30.77 \\
\hline 3 & Bonnet macaque & 19.23 \\
\hline 4 & Sambar deer & 5.69 \\
\hline 5 & Porcupine & 2 \\
\hline & Total & 100 \\
\hline
\end{tabular}

Table 5: Percentage of plots raided by different wild animals in different settlements.

Effectiveness of the protection methods: The protection methods employed in different locations sampled in the settlements could be broadly classified in to five categories:

a. Guarding at during night hours

b. Ordinary Fencing: - Fencing by various materials (barbed wire, unpalatable vegetative matters)

c. Electric Fence: - High voltage electric fences around the cultivated area

d. Kayyala (stone or rubble wall) and check dams

The effectiveness of the methods employed varied according to the locations. Electric fencing, which was observed in Kothapara, Mullallu, Memari, Kollathikavu and Kannampady settlements was found most effective. But it was observed that maintenance of the same was very poor and vegetation was crawling upon the fence.

Kayyala construction in Kothapara, Kumarikulam area has ensured the safety of farmers by preventing attack of wild animals. Check dams were constructed in places like Vakavanam, Chillalu and Anakuzhy areas for providing water to animals to keep away from settlements. Guarding during night hours and using unpalatable vegetative barriers found to be effective in certain areas.

\section{Threats}

\section{Human Habitations in and around Idukki WLS}

There are 12 hill men settlements are located within and outside the PA. They depend on the WLS for collection of firewood and NWFP and grazing their cattle. Tree felling was an issue during the study period but was found to be effectively tacked at the end of the study period. In the adjacent forest areas, a number of tribal and non-tribal settlements are found. The tribal settlements in the adjacent Range of Kottayam Forest Division are Anchuruli, Kappakkanam, Kozhimala, Maniyarankudy, Karimpinkanam (Churuli), etc. These people are depending on the forest for various livelihood activities such as collection bamboo, reed, firewood, etc. There is a proposal for electricity connection to the human settlements inside the WLS. Electric lines to the settlements may cause harm to wild animals if it is reachable to wild animals or not properly monitored.

\section{Cattle Grazing}

In the absence of large forests in the vicinity of the sanctuary, the cattle of the tribal settlements within the WLS are solely depending upon the PA. Besides these settlements, boundaries at Kuvalettam and Kothapara areas have fringe area human population. About 8001000 cattle are depending upon the PA and adjacent forest for fodder. Apart from that the settlers collect green fodder from the PA. These cattle could be source of contagious diseases to the wild animals such as anthrax, foot and mouth diseases, salmonellosis, etc. Hence grazing is a major problem in this area. However, periodic vaccination programme is being carried out by the PA management annually.

Feral Cattle: There are about 300 feral cattle (buffalos) are permanently exist within the PA (Plate 2). There are no possessors for these feral cattle and they become part of wild. Though these feral cattle compete with the wild animals for food and water, they form part of the food to the carnivores such as leopard and wild dog. During the study, a total of 13 herds of feral cattle were observed. Out of which, three herds were sighted with calves which reveals that the population breeds and there could be a steady growth in population.

\section{Fire}

Fire incidents are reported regularly from Idukki sanctuary. The fire season starts by February and last up to May. During the fire season grasslands gets fire which spreads fast due to the prevailing wind and destroys significantly the flora and fauna. Moist deciduous forests are also repeatedly affected by annual fire.

\section{Human Wildlife Conflict}

Though, presently this is not an issue it is a potential threat in the future. At present wild boar causes 


\section{International Journal of Zoology and Animal Biology}

considerable damage than elephants. The PA management immediately acts upon getting the application for wildlife damage and thus presently no havoc due to human-wildlife could be found in the PA. The compensation paid to the damage was also found to be least in most of the years. Hence presently this is not a serious issue.

\section{Highways through Forest}

There is no road network within WLS except a few jeepable roads to the tribal settlements. However, many roads with heavy vehicular traffic are found in the forest adjoining to Idukki WLS especially in Thodupuzha RF. Observation revealed the travellers passing through these roads do not cause much disturbance to the wild animals. However, the animals sometime found to risk while crossing the roads. No sign boards for the travellers are found at these critical locations.

\section{Habitat Degradation}

Habitat degradation was found to be accelerated through frequent fire and dependency of people living within and adjoining areas of the PA. Though the dependency issues are being tackled within the WLS, they should be focused on further reduction of resource dependency of local community.

\section{Water Scarcity in the Adjoining Areas of Idukki WLS}

Water scarcity is not an issue in the WLS as the Idukki reservoir exists in the PA. In addition, Periyar River, However, scarcity of water is an issue in Thodupuzha Range especially in the area between Adappan Mudi and Nagarampara Mudi and Kaithappara region where large extent of forest is totally dry during summer months.

\section{Conclusion}

The habitat of WLS is contiguous towards north-west to Thodupuzha RF and cut off at Tommankuthu. Hence this landscape is totally isolated and cut off from the main tract of elephant habitats extending from Munnar Forest Division on the north and Periyar Tiger Reserve on the south. In the entire landscape, the forest surrounded by the reservoir is the only congenial habitat for wildlife without much pressure as found in other regions of the landscape. Elephant is the prominent vertebrate found in the WLS and the population structure of elephants shows that the sex-ratio is highly skewed. Necessary steps alone help the viability of population of elephants in the sanctuary.

\section{Recommendations}

$>$ The dependency of local community within the WLS is presently being tackled through ecodevelopment activities. However, the Ecodevelopment Committees (EDCs) need to be strengthened to effectively implement activities relating to reduced resource collection. It was found that the EDC members are not oriented towards such programme. Hence, the activities should be focused on the reduction of resources such as NWFP and firewood.

$>$ Marketing of NWFP can be channeled through the EDCs with value additions. Support can be extended for marketing their agricultural products may be ensured so that the dependent community would get more income that would reduce the resource collection from forest.

$>$ Cultivation of crops using chemical fertilizers, pesticides and weedicides may be avoided in the human settlements surrounded by forest. Through ecodevelopment supply of organic manure may be taken up as an activity. As organic products fetch more price, this may be taken up on priority basis in future. Trainings and awareness campaigns to the local community would change the mindset and enhance serene coexistence of local community within WLS.

$>$ Though tree felling was found to be reduced at the end of the study period, it is a potential threat. The PA management should keep vigil on this issue and control the threat.

$>$ The proposed electrification to the human settlements inside the WLS needs to be carefully carried out. Electric lines to the settlements may be taken through underground cabling that will prevent casualty to wild animals. Even within the settlements, the undergrowth needs to be regularly cleared under the electric lines through electric posts to keep the vegetation touching the electric lines that will cause serious fatal to the wild animals. Regular monitoring of these electric lines in association with the KSEB may be ensured by the PA management.

$>$ Collection of resources such as bamboo, reed, firewood, etc in the adjacent forest areas surrounding the WLS should be tackled through VSS/EDC.

$>$ Annual vaccination of cattle within and outside the WLS should be carried out with the support of Animal Husbandry Department to prevent disease to wild animals. 


\section{International Journal of Zoology and Animal Biology}

The ecodevelopment activity should focus on reduction of local breed cattle in place of hybrid varieties so that the cattle can be stall fed. Moreover, this activity will increase income to local community that will reduce their dependency on forest.

$>$ The PA management may explore possibility of marketing the milk of cattle that forage in the forest under eco-milk label. This will also fetch sufficient income to the local community.

$>$ As the existing feral cattle in the PA has already became wild and considerably contribute to the food of existing carnivores in the PA, removal of the feral cattle is debatable. Apart from competition for food, the feral cattle may a potential source for spread of especially the contagious disease to wild animals. In this case controlling the population and its growth may be taken up by the management. A possible solution for controlling the feral cattle population could be castration of males that will reduce the population growth. Another solution could be removal of the feral cattle by suitable method (shooting, capturing live with net or similar means) and the meat can be sold through EDCs. In the absence of feral cattle reintroduction of gaur in the Sanctuary may be explored.

$>$ Fire should be strictly prevented in the surrounding areas of evergreen forest patches and moist deciduous forests. However, in the tall grass areas, controlled burning or cutting of grass should be practiced on rotation basis so as to provide fresh fodder to wild animals as well as to reduce potential extensive fire in the region. Apart from the conventional fire preventive measures, participatory fire management may be strengthened to control fire as per the prescription given in the guidelines circulated by KFD.

$>$ For preventing the human-wildlife conflict the existing structures of protective measures such as solar power fencing, kaiyala, etc should be periodically maintained. The local support for the maintenance of the same should be explored for long sustenance of the protective measures. In areas where soil is compact, elephant proof trench may be constructed.

> Vegetative barriers with agave, Caesalpinia sappan, Plumbago sp. (Koduveli) in areas around the settlements wherever it is feasible and effective should be taken up through Eco development activities.

$>$ Timely payment of compensation should be given to keep up good relation between the PA and people and to avoid any untoward activities by the local communities.

$>$ In territorial forest divisions, establishing monoculture should be avoided as the existing forest patches are already very tiny for the larger animals and highly fragmented. Habitat enrichment activities should be taken up in such patches to provide sufficient habitats at least to the short/narrow-ranging animals.

$>$ In areas where animals crosses the road, sign boards and warning boards should be erected in critical locations to avoid untoward activities of the travellers through the roads especially the heavy vehicular traffic roads.

$>$ Habitat enrichment activities such as removal of exotic weeds, maintenance of marshy areas and grasslands, maintenance of waterholes, controlled pre-burning should be carried out to retain the potential habitats for herbivores. Waterholes may be developed in the gaps where no water is available within a reach of $1 \mathrm{~km}$ radius. The areas between Adappan Mudi and Nagarampara Mudi and Kaithappara region may be given priority to provide water to animals especially in the summer months.

$>$ Weeding along the reservoir fringe will ensure sufficient fodder to herbivores during the pinch period.

$>$ Annual monitoring of wild animals including elephants should be taken up by the PA management to monitor the trend in population.

$>$ Encroachments within and surrounding areas of the WLS should strictly be prevented so as to prevent further reduction in the habitat.

$>$ The villagers can be sensitized about the problems presently faced by elephants in the isolated forests of Idukki WLS and the mitigate measures of long-term survival of such endangered population.

$>$ Presently tourism is not a major issue in the WLS. However, there is a possibility of pressure due to tourism under the ecotourism label that will create havoc to the existing isolated elephant habitat. If any tourism activity is proposed to be initiated in future, an impact study should be carried out well in advance.

$>$ As the habitat is totally isolated and no possible connectivity to the potential habitats which are miles away from this habitat, the elephants suffer due to inbreeding. Inbreeding results in increased homozygosity, which can increase the chances of offspring being affected by recessive or deleterious traits and leads to inbreeding depression (decreased fitness of a population). Hence, introduction of males from other population might enhance the change in the gene pool of this small population. Presently almost all elephant population in the state and in the country suffers due to highly skewed sex ratio. Thus it is not advisable to remove the males from those populations. However, if any male create havoc and warranted to be removed from any population, the same may be 


\section{International Journal of Zoology and Animal Biology}

released in Idukki with radio telemetry for further monitoring and initiate actions based on observation.

> PA management should ensure stringent protection against all habitat degradation activities as the area within and outside the WLS are highly potential for ganja cultivation and other illegal activities.

$>$ No further development activities should be taken up in the existing isolated and fragmented elephant habitat in Idukki WLS that will totally wipe out the existing population of elephants and other herbivores in the Idukki landscape.

> As part of a long-term monitoring, the mortality and natality of the elephant population should be initiated by either the PA management or engaging and a team of experts to understand the population dynamics and take appropriate measures to avoid local extinction of elephant population, as had already happened to the gaur population in this isolated landscape.

\section{Acknowledgement}

We are much indebted to Sri. Vallil Gopinathan IFS, Chief Conservator of Forests (Wildlife) and Chief Wildlife Warden, Kerala, Sri. A.K. Bhardwaj, IFS, Field Director (Project Tiger), Sri. Pramod G. Krishnan IFS and Smt. Padma Mahanti, IFS, Deputy Directors and Member Secretaries of Periyar Foundation and Sri. Simon K. Francis, Asst. Field Director for giving this opportunity to work on management of elephants in Idukki Wildlife Sanctuary. Sri. Cheriyan Kunju, Wildlife Warden and Sri. Fen Antony, Asst. Wildlife Warden helped in many ways during our field work at Idukki WLS. We are also thankful to the field staff and watchers of Idukki Wildlife Sanctuary who accompanied during our field visit.

\section{References}

1. Nair PV, Balasubramanyan K (1985) Long-term Environmental and Ecological Impact of Multipurpose River valley Projects. KFRI Research Report No. 26, Kerala Forest Research Institute, Peechi.

2. Jain SK, Nair NC (1982) Long term environmental ecological impacts of multipurpose river valley projects with special reference to Idukki, Kerala. Subproject IVA. Annual Report. Botanical Survey of India, Coimbatore. Janzen DH, et al. (1972). The uncertain future of the tropics. Nat Hist 8(1): 80-94.

3. Dikshit BK (1983) Taxonomy and Ecology of the freshwater algae of Idukki. In: Trisal CL, Ramanathan NL, et al. Long term Environmental and Ecological impacts of multipurpose river valley project-A mid term report. Department of Environment, New Delhi pp: 160- 177.

4. Trisal CL, Ramachandran NL (1983) Long term Environmental and Ecological impacts of multipurpose river valley project-A midterm report. Department of Environment, New Delhi pp: 160-177.

5. Singh J (1983) The study of successional pattern and conservation methodology in disturbed and undisturbed ecosystems. In: Trisal CL, Ramanathan $\mathrm{NL}$, et al. Long term Environmental and Ecological impacts of multipurpose river valley project-A mid term report. Department of Environment, New Delhi pp: 160-177.

6. Gopinath P, Jayakrishnan TN (1984) A study on the piscifauna of Idukki reservoir and catchment area. J Fish Technol 21: 129-133.

7. Wason A (1984) The status of wild mammals in Idukki hydro-electric Project area in Kerala, India. Environment and Ecology 2: 266-270.

8. Cherian PT (1985a) Ecological impact studies on the invertebrates of Idukki and on some fauna in the lower reaches of Periyar and Muvattupuzha. In: Cherian PT, et al. Long term Environmental and Ecological Impacts of Multipurpose River Valley Projects with special reference to Idukki, Kerala. Zoological Survey of India Pp: 12-56.

9. Cherian PT (1985b) Ecological impacts of Idukki hydel project on the amphibians and reptiles of the area. In: (P.T.Cherian) Long term Environmental and Ecological Impacts of Multipurpose River Valley Projects with special reference to Idukki, Kerala. Zoological Survey of India 129-151 pp: 27.

10. Khatri TC (1985) Limnological studies of Idukki reservoir. In: Cherian PT, et al. Long term Environmental and Ecological Impacts of Multipurpose River Valley Projects with special reference to Idukki, Kerala. Zoological Survey of India pp: 57-87.

11. Prasad NLNS (1985) Ecological impact studies with special reference to changes in the avifauna of Idukki hydro-electric project area. In: Cherian PT, et al. Long term Environmental and Ecological Impacts of Multipurpose River Valley Projects with special 
reference to Idukki, Kerala. Zoological Survey of India pp: 152-177.

12. Vinod TR (1994) Food and feeding habits of Asian elephants (Elephas maximus Linn.)-A case study of Idukki Wildlife Sanctuary. M.Sc. dissertation, College of Forestry, Vellanikara. Wason A 1984. The status of wild mammals in Idukki hydro-electric Project area in Kerala, India. Environment and Ecology 2: 266-270.

13. Easa PS (1997) Status, food and feeding of larger mammals in Idukki Wildlife Sanctuary. KFRI Research Report No. 134.

14. Easa PS, Jayaram K (1998) Population estimation of major mammals in the forests of Kerala-1997. Kerala forest Research Institute, Peechi and Kerala Forest Department, Thiruvananthapuram.

15. Easa PS, Sivaram M, Jayaram K (2002) Population estimation of major mammals in the forests of Kerala 2002. Kerala forest Research Institute, Peechi and Kerala Forest Department, Thiruvananthapuram.

16. Sivaram M, Ramachandran KK, Nair PV, Jayson EA (2005) Population estimation of wild elephants in the Elephant Reserves of Kerala State-2005. Kerala Forest Research Institute, Peechi, Kerla, India pp: 1-46.
17. Sivaram M, Ramachandran KK, Nair PV, Jayson EA (2007) Population Estimation of wild elephant in the Elephant Reserves of Kerala State.

18. Vinod TR, Cheeran JV (1997) Activity time budget of Asian elephants (Elephas maxmimus L.) in Idukki Wildlife Sanctuary, Kerala, South India. Indian Forester 123: 948-951.

19. Rajan PK (2001) The Management Plan for Idukki Wildlife Sanctuary. Kerala Forest and Wildlife Department, Thiruvananthapuram.

20. Laws RM (1966) Age criteria for the African elephant Loxodonta a. africana. East African Wildlife Journal 4: 1-37.

21. Laws RM, Parker ISC, Johnstone RCB (1975) Elephants and their Habitats. Clarendon Press, Oxford, UK.

22. Sukumar R (1985) Ecology of the Asian elephants (Elephas maximus) and its interaction with man in south India, Ph.D. thesis, Indian Institute of Science, Bangalore. 